\title{
Oestrogen Receptor- $\alpha$-Immunoreactive Neurones Project to the Suprachiasmatic Nucleus of the Female Syrian Hamster
}

\author{
H. O. de la Iglesia, J. D. Blaustein and E. L. Bittman \\ Center for Neuroendocrine Studies, University of Massachusetts, Amherst, MA, USA. \\ Key words: neuronal tracing, suprachiasmatic nucleus, oestrogen receptor, immunocytochemistry, luteinising hormone surge.
}

\begin{abstract}
Ovarian steroid hormones regulate circadian period and phase, but classical receptors for these hormones are absent in the circadian pacemaker localized in the suprachiasmatic nucleus of the hypothalamus (SCN). In order to determine whether effects of oestrogen may be exerted through steroid-binding systems afferent to the SCN we have performed double label immunocytochemistry for oestrogen receptor- $\alpha(E R-\alpha)$ and the retrograde tracer cholera toxin B subunit (CtB) after its application to the SCN. Most of the areas that contain ER- $\alpha$-immunoreactive (ER $\alpha$-ir) cells also contained cells afferent to the SCN. The percentage of neurones afferent to the SCN which show $\mathrm{ER} \alpha$-immunoreactivity varies between areas. As many as one-third of the neurones afferent to the SCN in some parts of the preoptic area and the corticomedial amygdala are ER $\alpha$-ir. Very few of the afferent neurones from the septum and the central grey are ER $\alpha$-ir, whereas an intermediate proportion of afferents from the bed nucleus of the stria terminalis and the arcuate nucleus are $\mathrm{ER} \alpha$-ir. Our retrograde tracing results were compared with results of anterograde tracing from some of the sites containing SCN afferents. Using a combined retrograde and anterograde tracing technique we tested the possibility that single $\mathrm{ER} \alpha$-ir neurones afferent to the SCN could receive reciprocal innervation by SCN efferents. Although we found SCN input to some SCN afferent neurones, we found no evidence of reciprocity between single ER $\alpha$-ir cells and the SCN. Our results indicate the existence of oestrogen binding systems afferent to the SCN. These neuroanatomical pathways may mediate effects of gonadal steroid hormones on circadian rhythms.
\end{abstract}

Ovarian steroid hormones modulate rodent circadian rhythms. In both rats and Syrian hamsters the phase and amplitude of circadian locomotor activity changes systematically across the oestrous cycle as a result of the changing levels of estradiol (E2) and progesterone (1-6). In ovariectomized (OVX) animals E2 increases the amplitude, shortens the period, and changes the phase of onset and distribution of circadian activity (4, 7-9). Progesterone antagonizes these E2-induced effects $(8,10-12)$. Furthermore, E2 prevents 'splitting' of circadian wheel-running in OVX animals (13-15). The capacity of ovarian hormones to modulate circadian period indicates that these steroids exert their effect directly or indirectly on the circadian pacemaker.

The suprachiasmatic nuclei (SCN) of the rodent hypothalamus contain the master circadian oscillator responsible for the generation of behavioural circadian rhythms (16). E2 could affect the circadian system by acting directly on these nuclei. In theory, the effects of this steroid could be mediated (1) by classical receptors located in the cytosolic and nuclear compartments of cells within the brain $(17,18)$; and/or (2) by membrane receptors which may mediate effects of steroid hormones $(19,20)$. Examination of the distribution of oestrogen receptor- $\alpha(E R-\alpha)$ in the female rat and hamster brain by immunocytochemistry (21-23), autoradiography using radiolabelled steroids $(24,25)$, or in-situ hybridization for ER- $\alpha$ mRNA (26), fails to demonstrate expression of ER- $\alpha$ in the SCN. This suggests that the actions of E2 on the SCN are mediated by either non-classical steroid binding sites, e.g. membrane receptors, by ER- $\alpha$ binding sites which are afferent to the $\mathrm{SCN}$, or by other oestrogen receptor subtypes within or in neuronal afferents to the SCN.

In order to examine the second possibility, we mapped $\mathrm{ER} \alpha$ immunoreactive (ir)-cells which project to the SCN by combining retrograde tracing of cells afferent to the SCN

Correspondence to: Horacio O. de la Iglesia, Neurology Department, Room S5-746, University of Massachusetts Medical Center, 55 Lake Avenue North, Worcester, MA 01655, USA (e-mail: hacho@bio.umass.edu). 
with immunocytochemistry for oestrogen receptors. Previous studies (27-30) have indicated afferent input to the either the shell or the core of the SCN from the retina, the preoptic area, the anterior hypothalamus, the intergeniculate and paraventricular nuclei of the thalamus, and the midbrain raphe, but have not identified the steroid receptor content of these cells. We also performed anterograde tracing studies to confirm our retrograde tracing results and analysed the possibility that individual ER $\alpha$-ir neurones afferent to the SCN might also be targets of SCN efferent fibres.

\section{Materials and methods}

Female golden hamsters (LVG strain) weighing between 125 and $200 \mathrm{~g}$, purchased from Charles River (Wilmington, MA, USA) or from our own colony, were used in this study. Animals were housed in $14 \mathrm{~h}: 10 \mathrm{~h}$ light: dark cycle in a temperature-controlled room. Oestrous cycles were monitored by daily vaginal smears, and only animals that showed at least five successive regular cycles were used. Animals used for retrograde tracing studies and animals used for combined retrograde and anterograde tracing studies were ovariectomized in diestrus I or II under pentobarbital anaesthesia (i.p. $10.37 \mathrm{mg} / 100 \mathrm{~g}$ body weight), as endogenous $\mathrm{E} 2$ interferes with binding of the H222 antibody (see below).

\section{Retrograde tracer application}

Either immediately or up to 3 weeks after ovariectomy, animals under pentobarbital anaesthesia received cholera toxin $\mathrm{B}$ subunit $(\mathrm{CtB})$ iontophoretic applications. Animals were placed in a stereotaxic device and $\mathrm{CtB}(5 \mathrm{mg} / \mathrm{ml}$ in $0.1 \mathrm{M}$ phosphate buffer; List Laboratories, Campbell, CA, USA) was unilaterally applied by iontophoresis. A glass pipette with a $40-50 \mu \mathrm{m}$ tip diameter was lowered to the SCN. The stereotaxic co-ordinates used were $1 \mathrm{~mm}$ anterior to bregma, $0.75 \mathrm{~mm}$ lateral to the sinus, and $7.95 \mathrm{~mm}$ below the dura, with a $5^{\circ}$ angle and the skull levelled between lambda and bregma. A positive current of $2 \mu \mathrm{A}$ provided by a constant-current source (Transkinetics, Canton, MA, USA; model CS3) was applied during $10 \mathrm{~min}$, alternatively turning the current on and off every $8 \mathrm{~s}$.

After a survival time of 15-20 days animals were deeply anaesthetized with sodium pentobarbital (i.p. $20 \mathrm{mg} / 100 \mathrm{~g}$ body weight). After an injection of 5000 units of heparin (Rugby Laboratories, Norcross, GA, USA) into the left ventricle hamsters were perfused transcardially $(25 \mathrm{ml} / \mathrm{min})$ with $100 \mathrm{ml}$ of $0.01 \mathrm{M}$ phosphate-buffered saline ( $\mathrm{pH} 7.3$ ) followed by $250 \mathrm{ml}$ of $2 \%$ paraformaldehyde, $0.2 \%$ glutaraldehyde in $0.1 \mathrm{M}$ phosphate buffer ( $\mathrm{pH} 7.3$ ). The brains were removed and infiltrated overnight in phosphate-buffered $20 \%$ sucrose solution. Sections were cut on a freezing microtome into $40 \mu \mathrm{m}$ coronal sections. Series of one-in-four sections including the diagonal band (rostral extent) through the dorsal raphe (caudal extent) were cut and stored in cryoprotectant $(31)$ at $-20^{\circ} \mathrm{C}$ until immunocytochemistry was carried out.

One set of sections was used to determine for each animal the site of the $\mathrm{CtB}$ deposit. Free floating sections were rinsed three times for $5 \mathrm{~min}$ each with $0.05 \mathrm{M}$ Tris-buffered saline (TBS, $\mathrm{pH} 7.6$ ) followed by $0.5 \% \mathrm{NaBH}_{4}$ in TBS for $30 \mathrm{~min}$. Sections were then rinsed three times for $5 \mathrm{~min}$ each with TBS followed by $20 \mathrm{~min}$ in $0.5 \% \mathrm{H}_{2} \mathrm{O}_{2}$ in TBS for $20 \mathrm{~min}$. Sections were rinsed three times for 5 min each with TBS followed by $20 \%$ normal rabbit serum, $0.5 \%$ Triton X-100 (Tx) in TBS for 10-20 min. Sections were incubated in goat anti-CtB antibody 1:5000 (List Laboratories) in 2\% normal rabbit serum, $0.5 \%$ Tx in TBS (buffer 1) overnight at room temperature followed by three 5 -min rinses in buffer 1 and by incubation in $5 \mu \mathrm{g} / \mathrm{ml}$ biotinylated rabbit antigoat (Vector Laboratories, Burlingame, CA, USA) in buffer 1 for $1 \mathrm{~h}$. Following two 5-min rinses in buffer 1 and one 5-min rinse in TBS sections were incubated with avidin-biotin peroxidase complex (ABC, Elite kit, Vector Laboratories), according to supplier's instructions. Following three 5 -min rinses in TBS, sections were incubated in $0.05 \%$ diaminobenzidine, $0.05 \% \mathrm{H}_{2} \mathrm{O}_{2}$ in TBS for 5-10 min. Sections were rinsed several times in TBS, mounted in gelatin/chromium potassium sulphate-subbed slides, dried and coverslipped with mounting medium.

A second set of sections of only those brains with $\mathrm{CtB}$ applications restricted to the SCN was processed for double label immunocytochemistry for $\mathrm{CtB}$ and ER- $\alpha$. Free floating sections were rinsed three times for $5 \mathrm{~min}$ each in TBS followed by $0.5 \% \mathrm{NaBH}_{4}$ in TBS for $30 \mathrm{~min}$. Sections were then rinsed three times for $5 \mathrm{~min}$ each with TBS followed by $20 \mathrm{~min}$ in $0.5 \% \mathrm{H}_{2} \mathrm{O}_{2}$ in TBS for $20 \mathrm{~min}$. Sections were rinsed three times for 5 min each with TBS followed by $1 \%$ bovine serum albumin, $20 \%$ normal rabbit serum, $0.5 \% \mathrm{Tx}$ in TBS for $20 \mathrm{~min}$. This was followed by incubation in $1.3 \mu \mathrm{g} / \mathrm{ml}$ of rat antiER-primary antibody (H222, Abbott Laboratories, North Chicago, IL, USA) in TBS containing $0.5 \% \mathrm{Tx}, 0.1 \%$ gelatin, and $0.02 \% \mathrm{NaN}_{3}$ (buffer 2), for $72 \mathrm{~h}$ at $4{ }^{\circ} \mathrm{C}$. Sections were rinsed three times for 5 min each with buffer 2 followed by incubation in $6 \mu \mathrm{g} / \mathrm{ml}$ biotinylated rabbit antirat (Vector Laboratories) in buffer 2 for $90 \mathrm{~min}$. Following two 5-min rinses in buffer 2 and one 5-min rinse in TBS, sections were incubated with avidin-biotin peroxidase complex for $90 \mathrm{~min}$. Following three 5-min rinses in TBS sections were incubated in TBS containing $0.05 \%$ diaminobenzidine (DAB), $10 \mathrm{mM}$ nickel-ammonium sulphate, $2 \mathrm{M}$ sodium acetate, $49 \mathrm{mM}$ ammonium chloride, $0.3 \% \beta$-D-glucose, 10 units $/ \mathrm{ml}$ glucose oxidase for less than $5 \mathrm{~min}$ and then rinsed several times in TBS. Sections were then processed for CtB immunocytochemistry as described above, but in this case starting with the incubation in the anti-CtB antibody.

Sections were mounted on slides, coverslipped with mounting media and inspected using a Zeiss Axioscope at $630 \times$ magnification. The existence of $\mathrm{ER} \alpha$-ir -cells projecting to the SCN was determined by the presence of doublelabelled cells. A double-labelled cell was defined as a brown-stained cell, indicative of $\mathrm{CtB}$, with a purple-stained nucleus, indicative of ER- $\alpha$. Cells were counted on the ipsilateral side of the tracer application, in all the sections present in the set (one out of four sets of $40 \mu \mathrm{m}$-thick sections). Cells were counted only in those regions where $\mathrm{CtB}$-stained cells and $\mathrm{ER} \alpha$-ir cells were co-localized. Given the variability on the distribution of CtB-stained between animals, the specific areas in which cells were counted differed between animals. Due to the lack of an atlas of the hamster brain, the Paxinos and Watson Atlas (32) of the rat brain was used as anatomical reference to subdivide the areas where ER- $\alpha$ - and CtB-immunoreactive cells were co-localized. The terms striohypothalamic and septohypothalamic nuclei refer to a group of ER- $\alpha$ stained cells consistently found in the areas labelled as such nuclei in this atlas. The amygdala was subdivided according to Price et al. (33). The term medial preoptic area is used throughout the paper to refer to the medial preoptic area proper, excluding the nuclei included within this area. No distinction between parvocellular and magnocellular subdivisions of hypothalamic nuclei was made in the analysis of results

All figures were generated by taking photographic slides with a Zeiss Axioscope, using Kodak Ektachrome film, scanning them with a slide scanner into a Macintosh computer, and printing them, using Adobe Photoshop, in a colour laser printer.

\section{Anterograde tracer application}

Intact females under pentobarbital anaesthesia were placed in a stereotaxic device and the anterograde tracer Phaseolus vulgaris leucoaglutinin $(2.5 \%$ PHA-L, Vector Laboratories, in sodium phosphate buffered saline, $\mathrm{pH} 8.0$ ) was unilaterally applied by iontophoresis. A glass pipette with a $30-45 \mu \mathrm{m}$ tip diameter was targeted at either the preoptic area or the corticomedial amygdala. The stereotaxic coordinates employed for the preoptic area were $1.5 \mathrm{~mm}$ anterior to bregma, $0.75 \mathrm{~mm}$ lateral to the sinus, and $7.6 \mathrm{~mm}$ below the dura, with a $5^{\circ}$ angle. The stereotaxic co-ordinates employed for the amygdala were $0.2 \mathrm{~mm}$ anterior or $0.7 \mathrm{~mm}$ posterior to bregma, $3 \mathrm{~mm}$ lateral to the sinus, and $7.5 \mathrm{~mm}$ below the dura, with a $0^{\circ}$ angle. A current of $8 \mu \mathrm{A}$ was applied during $10 \mathrm{~min}$, alternatively turning the current on and off every $8 \mathrm{~s}$.

After a survival time of 15-20 days animals were deeply anaesthetized and perfused following the same protocol as in the retrograde tracer application experiment except that the phosphate-buffered saline was followed by $250 \mathrm{ml}$ of $4 \%$ paraformaldehyde in $0.1 \mathrm{M}$ phosphate buffer ( $\mathrm{pH} 7.3$ ). Brains were removed and postfixed overnight in the same fixative and infiltrated overnight in phosphate-buffered $20 \%$ sucrose solution. Sections were cut in a freezing microtome into $40 \mu \mathrm{m}$ coronal sections. Series of one-in-four sections including the site of tracer application through the $\mathrm{SCN}$ were cut and stored in cryoprotectant at $-20^{\circ} \mathrm{C}$ until immunocytochemistry was carried out.

One set of sections was used to determine for each animal the site of the PHA-L deposit and whether anterogradely labelled fibres were localized at the SCN. Free floating sections were rinsed three times for $5 \mathrm{~min}$ each with $0.05 \mathrm{M}$ Tris-buffered saline (TBS, pH 7.6) followed by $0.5 \% \mathrm{NaBH}_{4}$ in TBS for $30 \mathrm{~min}$. Sections were then rinsed three times for $5 \mathrm{~min}$ each with TBS followed by $20 \%$ normal rabbit serum, $0.5 \%$ Tx in TBS for $10-20 \mathrm{~min}$. Sections were incubated in goat anti-PHA-L antibody 1:2000 (Vector Laboratories) in buffer 1 overnight at room temperature. Following addition of primary antibody the protocol was identical to that for single labelling of $\mathrm{CtB}$ described above. 


\section{Combined retrograde and anterograde tracer application}

A modification of a protocol provided by L. M. Coolen and R. I. Wood was used $(34,35)$. Two weeks after ovariectomy, animals under pentobarbital anaesthesia received iontophoretic applications with a solution containing equal volumes of the $\mathrm{CtB}$ and PHA-L solutions used in the above experiments. A glass pipette with a $30-45 \mu \mathrm{m}$ tip diameter was lowered at the $\mathrm{SCN}$, using the same co-ordinates as in the retrograde tracing study. A current of $4 \mu \mathrm{A}$ was applied during $10 \mathrm{~min}$, alternatively turning the current on and off every $8 \mathrm{~s}$. After a survival time of 15-20 days animals were perfused and brains treated as in the retrograde tracing study. One set of sections was used to determine the site of tracer application in each animal. These sections were processed for single labelling of PHA-L according to the protocol in the anterograde tracing study.

A second set of sections of only those brains with tracer applications centred at the SCN was processed for immunocytochemistry for PHA-L, ER$\alpha$ and CtB. Free floating sections were rinsed three times for $5 \mathrm{~min}$ each in TBS followed by $0.5 \% \mathrm{NaBH}_{4}$ in TBS for $30 \mathrm{~min}$. Sections were then rinsed three times for $5 \mathrm{~min}$ each with TBS followed by $20 \mathrm{~min}$ in $0.5 \% \mathrm{H}_{2} \mathrm{O}_{2}$ in TBS for $20 \mathrm{~min}$. Sections were rinsed three times for $5 \mathrm{~min}$ each with TBS followed by $20 \%$ normal rabbit serum, $0.5 \%$ Tx in TBS for $20 \mathrm{~min}$. This was followed by simultaneous incubation in $1.3 \mu \mathrm{g} / \mathrm{ml} \mathrm{H} 222$ antibody and $1: 2000$ anti-PHA-L antibody in TBS containing $0.5 \% \mathrm{Tx}, 0.1 \%$ gelatin, $0.02 \% \mathrm{NaN}_{3}$ and $1 \%$ normal rabbit serum (buffer 3 ), for $72 \mathrm{~h}$ at $4{ }^{\circ} \mathrm{C}$. Sections were rinsed three times for 5 min each with buffer 3 followed by simultaneous incubation in $7.5 \mu \mathrm{g} / \mathrm{ml}$ biotinylated rabbit antirat and $7.5 \mathrm{mg} / \mathrm{ml}$ biotinylated rabbit antigoat in buffer 3 for $1 \mathrm{~h}$. Following two 5-min rinses in buffer 3 and one 5-min rinse in TBS, sections were incubated with avidin-biotin peroxidase complex for $1 \mathrm{~h}$. Following three 5-min rinses in TBS sections were incubated in TBS containing $0.025 \%$ diaminobenzidine (DAB), $0.04 \%$ nickel chloride, $0.0075 \% \mathrm{H}_{2} \mathrm{O}_{2}$ in TBS for $5-10 \mathrm{~min}$ and then rinsed several times in TBS. Sections were incubated in $1 \% \mathrm{H}_{2} \mathrm{O}_{2}$ in TBS for 10 min to block the remaining peroxidase activity and then rinsed three times in TBS. Sections were then processed for $\mathrm{CtB}$ immunocytochemistry as described in the retrograde tracing study, starting with the incubation in the anti-CtB antibody.

The existence of ER $\alpha$-ir cells with reciprocal projections to and from the SCN was determined in those areas where ER- $\alpha / \mathrm{CtB}$ double-labelled cells overlapped with PHA-L-stained fibres. An ER $\alpha$-ir cell with reciprocal projections was defined as an ER- $\alpha / \mathrm{CtB}$ double-labelled cell on which PHA-L fibre appositions could be seen. An apposition was defined as a Ni-DAB fibre found in the same plane of focus and in immediate contiguity with doublelabelled cells.

\section{Results}

\section{Retrograde tracing}

A total of 24 animals was used for this study. Six of these animals had $\mathrm{CtB}$ iontophoretic applications centred at the $\mathrm{SCN}$, although the precise localization within the nucleus was variable. Figure 1 shows microphotographs of coronal sections of two representative animals. In two cases the tracer filled the medial portion of the SCN (Fig. 1B), in one including only the rostral part. Two CtB applications filled the entire extent and a third application filled the lateral portion of the nucleus (Fig. 1A), in these cases some tracer spread to the adjacent hypothalamus. Finally, one iontophoretic application filled the SCN bilaterally throughout their entire extent. In every case, retrograde labelling was observed in brain areas previously demonstrated to project to the SCN. CtB-immunoreactive neurones were found within the intergeniculate leaflet of the thalamus and the periventricular preoptic area (Fig. 1C,D), both well known afferents of the $\operatorname{SCN}(27,28)$.

$\mathrm{CtB}$ applications which filled either the lateral extent of the SCN or the whole nucleus led to the greatest number of retrogradely labelled neurones. The distribution of afferent cells within different nuclei agrees in general with that described by other authors $(27,29)$. Figure 2 shows the distribution of

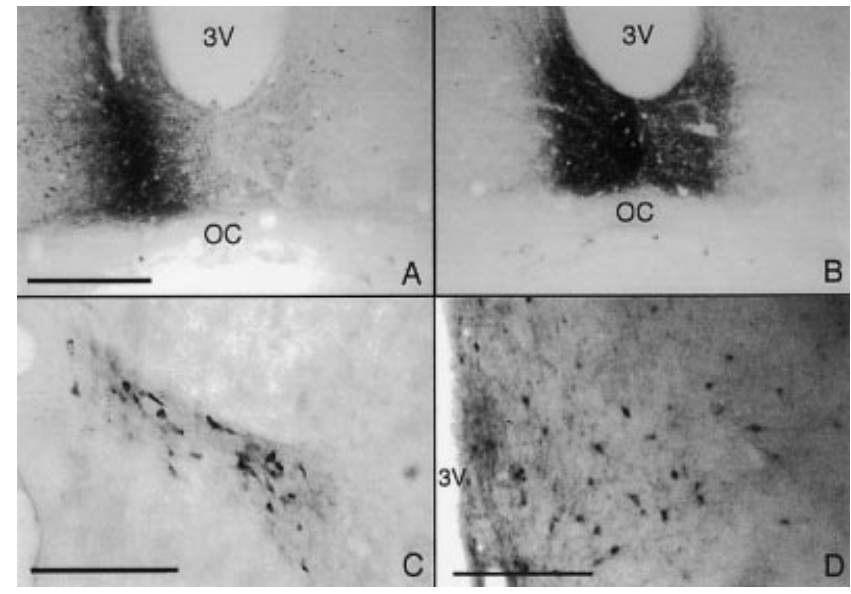

FIG. 1. Photomicrographs of sections immunostained for CtB. (A,B) unilateral tracer applications including the lateral and medial part of the SCN, respectively. (C,D) retrogradely labelled cells from two animals with $\mathrm{CtB}$ applications centred at the $\mathrm{SCN}$ in the thalamic intergeniculate leaflet and the medial preoptic area, respectively. $3 \mathrm{~V}$ : third ventricle; $\mathrm{OC}$ : optic chiasm. Upper scale bar $=300 \mu \mathrm{m}(\mathrm{A}, \mathrm{B})$; lower scale bars $=150 \mu \mathrm{m}$.

afferent cells to the $\mathrm{SCN}$ in a representative animal (tracer application shown in Fig. 1в). The highest densities of retrogradely labelled cells were found in the ventral, dorsal, and intermediate parts of the lateral septal nucleus, the vertical limb of the diagonal band at the level of the organum vasculosum of the lamina terminalis, the medial division of the bed nucleus of the stria terminalis, throughout the extent of the medial preoptic area, the contralateral SCN, the paraventricular hypothalamic nuclei, the paraventricular thalamic nucleus, and the intergeniculate leaflet. Intermediate densities of cells were found in the ventral division of the bed nucleus of the stria terminalis, the anterior hypothalamic area, the arcuate nucleus, the ventromedial hypothalamic nucleus, the midbrain dorsal and median raphe, and the central grey. Fewer cells were found in the dorsal tegmental nucleus, the dorsal and ventral premmamillary nuclei, and the zona incerta. A sparse distribution of CtB-ir cells was found in the ventral subiculum, on the boundary with the amygdalohippocampal area, and in one case in the dorsal nucleus of the lateral lemniscus.

In addition to these areas, retrograde labelling was observed in brain areas that have not been previously identified as afferent to the SCN (27). A large number of afferent cells was found in the striohypothalamic nucleus, and in the amygdala, particularly in the cortical and the medial amygdaloid nuclei, as well as in the amygdalohippocampal area. Intermediate densities of cells were present in the cingulate cortex, the infralimbic cortex, the medial tuberal nucleus, the dorsomedial hypothalamic nucleus, and the lateral parabrachial nucleus (see Table 1 and Fig. 2 for an estimation of relative cell densities). Fewer cells were found in the lateral preoptic area (medial region), the parastrial nucleus, the posterior hypothalamic area, the paratenial thalamic nucleus, the supramammilary nucleus, the ventral tegmental area, the peripeduncular nucleus, and the peduncolopontine tegmental nucleus.

Areas that contained high to intermediate densities of CtBstained cells but not ER $\alpha$-ir cells included the nucleus of the vertical limb of the diagonal at the level of the organum 

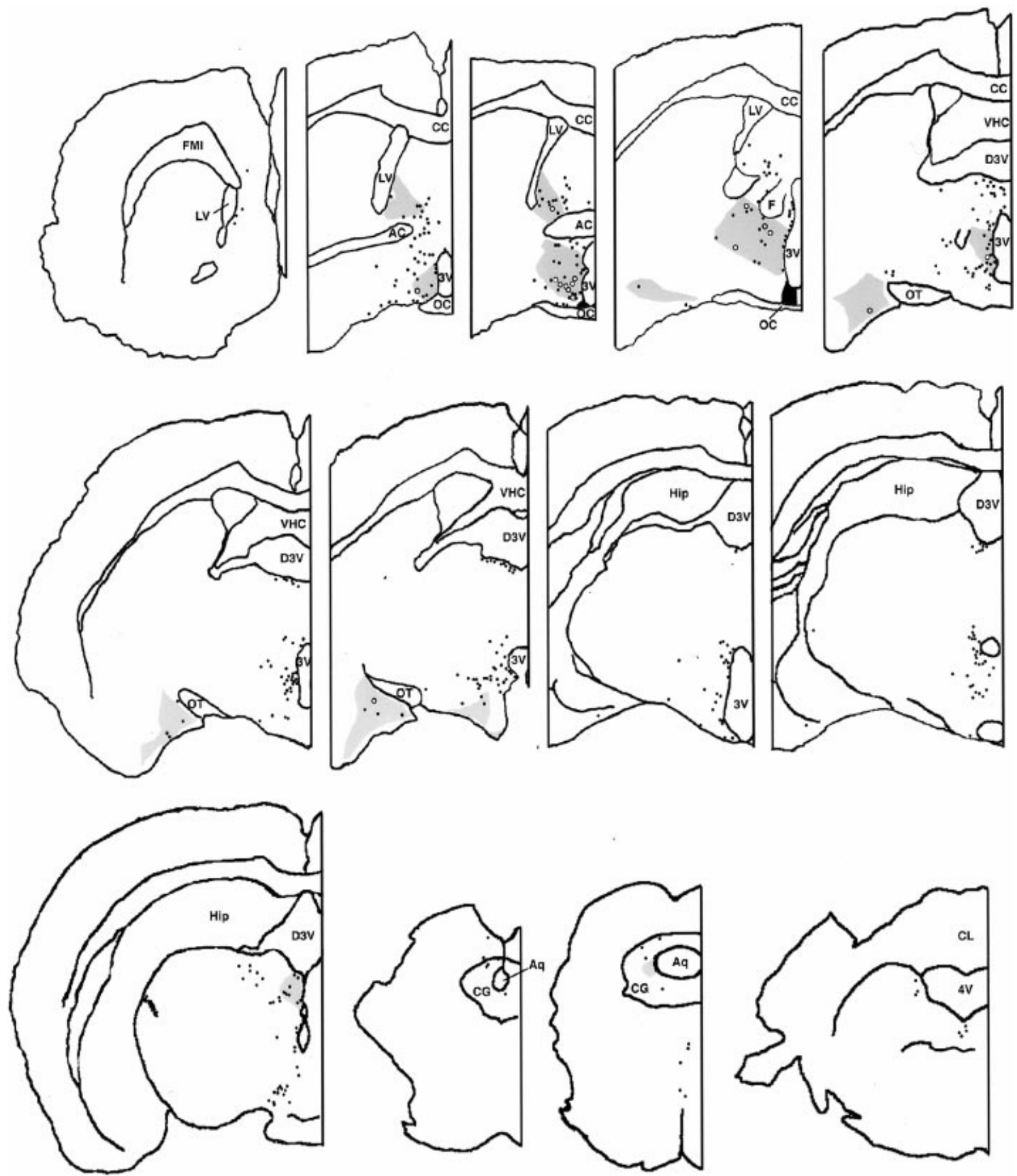

FIG. 2. Distribution of retrogradely labelled cells in an animal with a unilateral CtB application centred in the medial part of the SCN. Sections were immunostained for CtB and for ER- $\alpha$. Filled circles represent CtB-immunopositive cells; open circles represent cells that are immunopositive for CtB and ER- $\alpha$; grey areas represent the distribution of ER $\alpha$-ir cells. AC: anterior commissure, Aq: aqueduct, CC: corpus callosum, CG: central grey, CL: cerebellar lobules, D3V: dorsal third ventricle, F: fornix, FMI: forceps minor of the corpus callosum, Hip: hipocampus, LV: lateral ventricle, OC: optic chiasm, OT: optic tract, VHC: ventral hipocampal commissure, $3 \mathrm{~V}$ : third ventricle, $4 \mathrm{~V}$ : fourth ventricle.

vasculosum of the lamina terminalis, the contralateral SCN, the paraventricular hypothalamic nucleus, the dorsomedial hypothalamic nucleus, the paraventricular thalamic nucleus, and the intergeniculate leaflet (see Fig. 2 for an estimation of relative cell densities).

CtB-stained cells were found in almost all areas which contained populations of ER $\alpha$-ir neurones, including the preoptic area, the hypothalamus, the bed nucleus of the stria terminalis, the corticomedial amygdala, and the midbrain (see Fig. 2. and Table 1 for relative densities of retrogradely labelled cells). Table 1 shows the mean percentage of cells immunopositive for both ER- $\alpha$ and CtB (Fig. 3), over the total number of $\mathrm{CtB}$ cells, in each area defined by the Paxinos and Watson Atlas (32). Although variable between animals due to differences in the precise location of the $\mathrm{CtB}$ deposit within the SCN, the highest percentages of double-labelled 
TABLE 1. Mean Percentage of Cells Afferent to the SCN Which Are Oestrogen-Receptor Immunoreactive.

\begin{tabular}{|c|c|c|c|}
\hline Area & $\begin{array}{l}\text { Total CtB-stained } \\
\text { cells counted }\end{array}$ & $\begin{array}{l}\text { Weighted mean of } \\
\text { double-labelled cells }(\%)^{*}\end{array}$ & $\begin{array}{l}\text { Range among } \\
\text { animals }(\%)\end{array}$ \\
\hline \multicolumn{4}{|l|}{ Septum } \\
\hline Lateral septal nucleus, intermediate part & 144 & 1.8 & $0-14(5)$ \\
\hline Lateral septal nucleus, ventral part & 5.4 & 2.7 & $0-9(6)$ \\
\hline \multicolumn{4}{|l|}{ Bed nucleus of the stria terminalis } \\
\hline Medial division & 216 & 13.6 & $0-25(6)$ \\
\hline Ventral division & 42 & 1.4 & $0-7(5)$ \\
\hline \multicolumn{4}{|l|}{ Preoptic area and hypothalamus } \\
\hline Anterior hypothalamic area & 34 & 1.5 & $0-50(6)$ \\
\hline Anterior medial preoptic nucleus & 61 & 16.2 & $0-33(6)$ \\
\hline Anteroventral preoptic nucleus & 27 & 22.3 & $0-67(3)$ \\
\hline Arcuate nucleus & 93 & 10.6 & $0-17$ (4) \\
\hline Medial preoptic area & 465 & 20.3 & $8-33(6)$ \\
\hline Medial preoptic nucleus & 174 & 29.8 & $12.5-43(6)$ \\
\hline Medial tuberal nucleus & 64 & 17.2 & $10-50(4)$ \\
\hline Septohypothalamic nucleus & 271 & 8 & $5-18(6)$ \\
\hline Striohypothalamic nucleus & 27 & 33 & $0-55(4)$ \\
\hline Amygdala amygdalohippo-campal area & 74 & 27.3 & $15-59(3)$ \\
\hline Bed nucleus of the accessory olfactory tract & 19 & 5.3 & $0-50(3)$ \\
\hline Cortical amygdaloid nucleus & 47 & 23.2 & $0-50(4)$ \\
\hline Medial amygdaloid nucleus, anterior part & 219 & 6.8 & $0-16(6)$ \\
\hline Medial amygdaloid nucleus, posterior part & 132 & 12.1 & $0-27(5)$ \\
\hline \multicolumn{4}{|l|}{ Midbrain } \\
\hline Central grey & 48 & 4.1 & $0-22(3)$ \\
\hline
\end{tabular}

Data based on six animals with CtB iontophoretic applications restricted to the SCN. Number of animals in which ER $\alpha$-ir cells and CtB-stained cells were both found in each area is indicated in parentheses. Only those areas where both cell types were co-localized in at least three of six animals are included.

*The mean percentage for each area represents a mean between animals, weighted according to the number of CtB cells counted in each animal for that specific area.

cells were always found in the preoptic area, the anterior hypothalamus, the cortical amygdala and the amygdalohipocampal area. $\mathrm{CtB}$ applications which filled either the lateral extent of the SCN or the whole nucleus led to both a larger number of double-labelled cells (68-92 cells per animal) and a larger number of areas with double-labelled cells (16 areas per animal, as defined by the rat brain atlas), in comparison to applications which filled the medial SCN(24-37 doublelabelled cells per animal and nine areas with double-labelled cells per animal).

Although there was no obvious difference in the distribution of ER $\alpha$-ir cells between animals, the areas which contained $\mathrm{ER} \alpha$-ir cells, but not CtB-stained cells, differ from case to case, depending on the distribution of CtB-stained cells. These areas were more extensive in an animal with a tracer application including the rostral and medial portion of the SCN. In general, these areas included the lateral extent of the medial preoptic area, the lateral preoptic area, the lateral hypothalamic area, the intermediate (lateral division according to Alheid et al. (36)) and medial divisions of the bed nucleus of the stria terminalis, and the lateral extent of the central grey (Fig. 2).

\section{Anterograde tracing}

In order to confirm the results of retrograde tracing, 25 animals received PHA-L iontophoretic applications in the preoptic area. Four of these animals had PHA-L deposits that extended into the $\mathrm{SCN}$, and were therefore discarded from the analysis. Of the remaining animals, three had tracer applications that filled cells in the anterior medial preoptic nucleus, one had an application confined to the medial preoptic nucleus and three had applications which included the medial preoptic nucleus and/or the medial preoptic area, including a few cells of the rostral tip of the SCN. The remaining animals had either PHA-L applications in the third ventricle or the optic chiasm, or the site of the tracer deposit could not be determined. In all seven cases at which the iontophoretic application was centred at the preoptic area, sparse PHA-L fibres and varicosities could be seen within the core of the SCN. A greater density of fibres was evident at the shell of the nucleus, and a very dense plexus of fibres was seen at the peri-SCN area. Figure 4(A) shows a photograph of a representative PHA-L application that led to staining of fibres (Fig. 4C) and varicosities (Fig. 4E) at the SCN.

Ten animals received PHA-L iontophoretic applications in the amygdala. Eight of these animals had PHA-L applications filling cells at different subregions of the amygdala and in two of these animals the site of the PHA-L deposit could not be determined. Anterior applications that filled cells in both the dorsal and ventral divisions of the medial amygdala, and the cortical amygdaloid nucleus, labelled high densities of fibres and varicosities at the peri-SCN area, fewer at the shell of the SCN and very sparsely distributed fibres and varicosities within the core of the nucleus. A similar pattern of innervation of the SCN resulted when PHA-L filled cells within the anterolateral division of amygdalohipocampal area, but fewer PHA-L fibres were found in the SCN of 

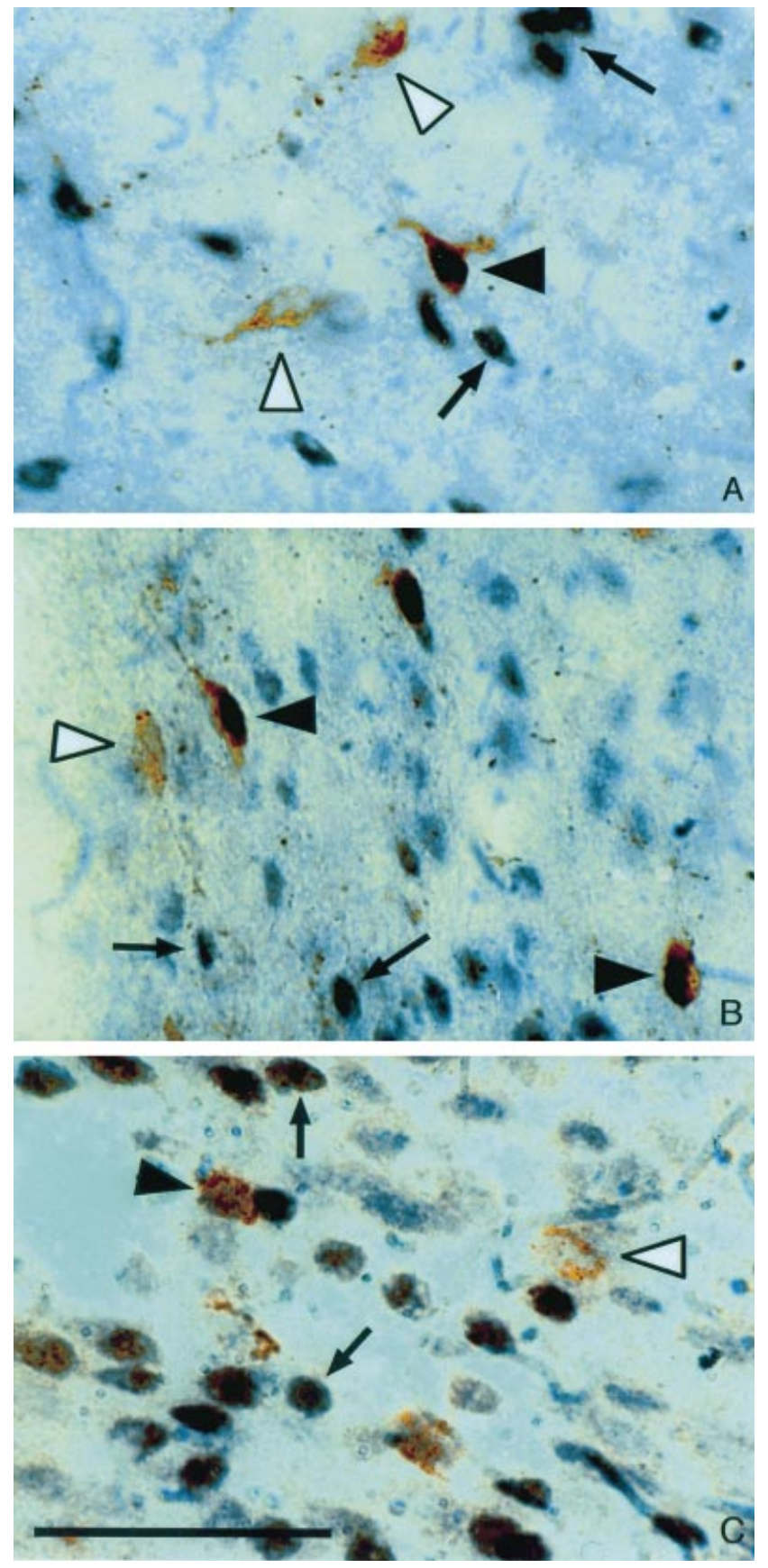

FIG. 3. High power photomicrographs of sections immunostained for cholera toxin B subunit (brown diaminobenzidine reaction) and oestrogen receptor (purple nickel-diaminobenzidine reaction) in the medial preoptic nucleus (A), the medial preoptic area (B), and the posteromedial cortical amygdaloid nucleus (C). White arrowheads: neurones immunoreactive to cholera toxin but not to oestrogen receptor. Black arrows: neurones immunoreactive to oestrogen receptor but not to cholera toxin. Black arrowheads: double-labelled cells. Scale bar $=50 \mu \mathrm{m}$.

hamsters with tracer deposits in more caudal divisions of this area or within the posterior cortical amygdaloid nucleus. Figure $4 \mathrm{~B}$ shows a photograph of a representative PHA-L application that led to fibre staining at the shell of the SCN and sparse labelling of fibres (Fig. 4D) and varicosities (Fig. 4F) within the nucleus.


FIG. 4. Photomicrographs of sections immunostained for PHA-L. (A,B) immunopositive cells at the application site of animals that received PHA-L iontophoretic applications in the preoptic area and the anterior amygdala (medial and cortical), respectively. (C,D) dark field microphotographs of PHA-L-stained fibres at the shell and core of the SCN of the same animals shown in (A) and (B), respectively. (E,F) high power microphotographs of PHA-L-stained varicosities at core of the SCN of the same animals shown in (A) and (B), respectively. Abbreviations as in Fig. 2. Scale bar $=250 \mu \mathrm{m}$ for A; $130 \mu \mathrm{m}(\mathrm{C}, \mathrm{D}) ; 650 \mu \mathrm{m}$ (B); $70 \mu \mathrm{m}(\mathrm{E}, \mathrm{F})$.

\section{Combined retrograde and anterograde tracing}

In order to examine the possibility that individual cells both project to the SCN and receive $\mathrm{SCN}$ input, 13 animals received iontophoretic applications with the CtB/PHA-L solution. In four of these animals the applications were centred in the SCN as judged by the PHA-L immunocytochemistry. The technique demonstrated that the distribution of SCN efferent fibres overlaps, in some cases, with that of 

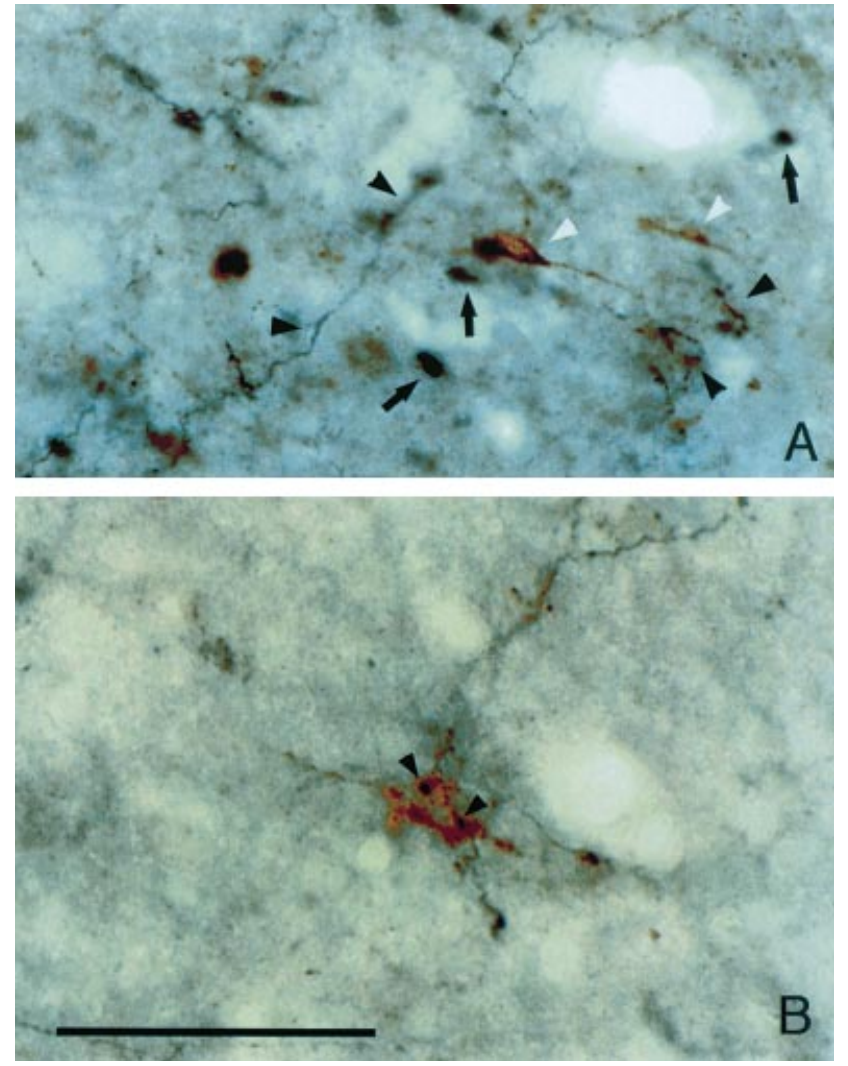

Fig. 5. High power microphotographs of sections from animals that received an iontophoretic application with a combination of anterograde and retrograde tracers at the SCN. (A) Co-localization of PHA-L-labelled fibres of SCN origin (black arrowheads), CtB-labelled cells afferent to the SCN (white arrowheads), and ER $\alpha$-ir neurones (black arrows) in the septohypothalamic nucleus. (B) appositions (black arrowheads) of PHA-L fibres of SCN origin on a CtB-stained cell afferent to the SCN located in the dorsolateral medial preoptic area. Abbreviations as in Fig. 2. Scale bar $=60 \mu \mathrm{m}$ (A); $45 \mu \mathrm{m}$ (B).

the ER- $\alpha / \mathrm{CtB}$ double-labelled cells. This was the case in animals where the tracers filled most of the $\mathrm{SCN}$, as in the case shown in Fig. 5A. In no area, however, were PHA-L fibres observed in close apposition to $\mathrm{CtB} / \mathrm{ER}-\alpha$-double labelled cells. Only within the paraventricular nucleus of the thalamus, the medial central grey (one case), and the dorsolateral medial preoptic area (one case, Fig. 5B) were PHA-L fibres of SCN origin found in close apposition to CtB-labelled SCN afferents.

\section{Discussion}

Our results confirm that there exists a high degree of regional co-localization of ER- $\alpha$-containing cells and SCN afferents. We have not found any $E R \alpha$-ir brain area which does not project to the SCN. This remarkable degree of overlap suggests an anatomical basis for regulation of the circadian pacemaker by ovarian steroids. The most important finding of this study is the identification of SCN afferent cells which contain ER- $\alpha$ in several brain areas (Table 1). The presence of oestrogen receptors in SCN afferents (as many as 30\% of retrogradely labelled cells in some portions of the preoptic area) provides a substrate for direct modulation of circadian rhythms by reproductive state. Since a great percentage of ER- $\alpha$-containing neurones may also contain oestrogeninduced progestin receptors (37) the present results suggest that the SCN may also receive direct input from progestin receptive neurones.

The distribution of SCN afferents in our study is not fully in agreement with that described by Pickard (27). In general, we have found more areas showing retrogradely labelled cells, particularly within the amygdala (Fig. 3C), the mediobasal hypothalamus and some sub-areas of the anterior hypothalamus. In contrast, the density of retrogradely labelled cells in the zona incerta, the ventral subiculum, and the dorsal nucleus of the lateral lemniscus was much lower in our study than previously described (27). Some technical considerations could explain these differences. The number and distribution of cells detected using any retrograde tracer depends on its sensitivity for axonal uptake, the localization and size of the tracer application, the degree of tracer spreading outside of the target nucleus, the degree of damage of en passant fibres, and the degree of selective uptake of the tracer by different cell types. CtB is a very sensitive retrograde tracer and is not taken up selectively by specific cell types (38). The possibility of uptake of the tracer by fibres of passage was reduced in our study by using current intensities in the iontophoresis procedure which minimize damage of axons coursing through the application site (38). Furthermore, our anterograde tracing studies in the amygdala and preoptic area suggest that the retrogradely labelled cells in these two areas was due to CtB uptake by terminals at the SCN. Thus, differences with other studies most likely arise from differences in the degree of spreading of retrograde tracer outside of the boundaries of the $\mathrm{SCN}$, and the use of a more sensitive retrograde tracer (CtB) in our study.

Although the PHA-L deposits in our anterograde tracing studies do not completely overlap with the distribution of double-labelled cells in the retrograde tracing experiments, these studies show that at least some of the retrogradely labelled subregions of the amygdala and preoptic area send few efferents to the core of the SCN and more dense projections to the shell of the nucleus and the peri-SCN area.

The distribution of amygdaloid efferents in the SCN region agrees in general with previous anterograde tracing studies of the medial amygdala in both hamsters (39) and rats (40). Gomez and Newman (39) showed that in the male hamster the posterodorsal medial amygdaloid nucleus sparsely innervates the shell of the $\mathrm{SCN}$, whereas the anterodorsal medial amygdaloid nucleus does not. However, we have found a denser distribution of corticomedial amygdaloid efferent fibres in the SCN. This difference could be due to the fact that our iontophoretic applications were more extensive and they were not segregated between the anterodorsal and posterodorsal divisions of the medial amygdaloid nucleus. Alternatively, there may exist sex differences in the amygdaloid pattern of innervation of the SCN. Indeed, the medial amygdaloid nucleus is sexually dimorphic with respect to both its size and synaptic organization (41), and its synaptic input to the preoptic area and anterior hypothalamus (42). In any case, the density of medial amygdaloid fibres innervating the SCN is lower than would be expected from our 
retrograde tracing study. The reasons for this could be that the retrograde tracing technique used is more sensitive than the anterograde tracing technique, or that PHA-L in not taken up by the specific cells innervating the SCN. The possibility that CtB-filled fibres of passage within the SCN seems unlikely, because these fibres would be also visualized in our anterograde tracing study.

To our knowledge, this is the first report of preoptic anterograde tracing studies in the hamster brain. The efferent projections from the preoptic area, particularly the anterior medial preoptic nucleus and the medial preoptic nucleus, to the SCN are confirmed by both retrograde and anterograde tracing studies reported in the present study. The innervation of the shell of the SCN, and particularly the peri-SCN area by preoptic area efferents has already been shown for the rat. Female rats show a more extensive innervation of the core of the SCN by anterior medial preoptic nucleus efferents than male rats $(30,43,44)$. The preoptic innervation of the SCN in the female hamster reported in this study resembles closely that of the female rat.

The surrounding peri-SCN area and the subparaventricular area are densely innervated by SCN efferents. These areas project back to the SCN and essentially to all the areas that are targets of SCN efferents, and they are recognized as relaying and modulatory areas for SCN output $(30,45-48)$. The dense innervation of the peri-SCN area (Fig. 4) and the subparaventricular area (data not shown) by the preoptic area and the medial amygdala may represent an input pathway controlling circadian oscillations, as well as a pathway modulating SCN output.

We have previously shown that the SCN projects to ER $\alpha$-ir cells (23) within some of the areas that contained doublelabelled ER- $\alpha / \mathrm{CtB}$ cells in the present study. However, the presence of single ER $\alpha$-ir cells that both project to the SCN and are targets of the SCN efferents could not be confirmed by our combined $\mathrm{CtB}$ and PHA-L studies. Although SCN afferent neurones and SCN efferent fibres overlap in several areas, single CtB-labelled cells showing appositions of SCN efferent fibres were only found within the paraventricular nucleus of the thalamus the peoptic area and the central grey. Although the paraventricular nucleus of the thalamus had been previously recognized as being both afferent and efferent to the SCN in rats and hamsters $(27,30,45-47)$, this is the first study showing that single thalamic neurones that project to the SCN may receive reciprocal SCN efferent projections.

Several studies support the notion that ovarian steroids modulate the phase and amplitude of circadian rhythms in rodents (1, 3-9), and apparently in one primate species (49). The ability of E2 to shorten circadian period $(4,9)$ suggests that the effects of reproductive state on circadian rhythms reflect an action of ovarian steroids on the circadian pacemaker. Our finding that the SCN is innervated by ER- $\alpha$ containing neurones suggests a direct anatomical connection subserving this control. Nevertheless, ovarian steroids may also regulate the circadian pacemaker via indirect pathways. This appears to be the case in the female rat, in which the effects of ovariectomy on circadian parameters depend on the access to running wheels (50).

Local application of E2 to the preoptic area and rostral anterior hypothalamic area increases wheel running activity
$(51,52)$ and lesions of these areas prevent the E2-induced increase in locomotor activity $(53,54)$. ER $\alpha$-ir cells in these two areas form a continuum that includes the medial preoptic area, the medial preoptic nucleus, and the rostral anterior hypothalamus (Fig. 2). Our study shows that these areas have the greatest proportions of SCN afferent neurones containing ER- $\alpha$ with up to one-third of the afferents being $\mathrm{ER} \alpha$-ir in some cases. This cell population could indirectly modify wheel running amplitude through effects on the circadian system. We have found almost no double-labelled cells in the anterior hypothalamic area. However, the distinction between the medial preoptic area and anterior hypothalamic area varies between studies, and other authors (52) have identified as anterior hypothalamus portions of the medial preoptic area delineated by Paxinos and Watson (32).

The pathways demonstrated by the present results provide a direct mechanism for steroidal regulation of circadian function. Several physiological and behavioural processes which exhibit a circadian rhythm, e.g. food intake and body temperature, also vary across the oestrous cycle (55). The pathways described here suggest a means by which the circadian control of these processes might be modulated by oestrogen. Other pathways, which could also contribute to reproductive modulation of circadian rhythms, are not excluded by our results. Membrane receptors for ovarian steroids within the $\operatorname{SCN}(19,20)$ represent a possible pathway, particularly considering the ability of a progesterone metabolite to allosterically modulate $\mathrm{GABA}_{\mathrm{A}}$ receptors in the $\mathrm{SCN}$ (56). Furthermore, SCN afferents containing the recently cloned ER- $\beta$ (57), not detected by our immunocytochemical technique, could represent another pathway for oestrogenic modulation of the circadian system. Interestingly, the paraventricular nucleus of the rat, one of the main hypothalamic areas afferent to the SCN, expresses high levels of ER- $\beta$ mRNA but not of ER- $\alpha$ mRNA $(58,59)$. Studies on the distribution of ER- $\beta$ mRNA-containing cells in the brain indicate that some SCN cells may express this receptor type. ER- $\beta$ mRNA seems to be present in low levels in the rat $\operatorname{SCN}(58,59)$, and is abundant in the SCN of the ER- $\alpha$ knockout mouse (60). Although unpublished observations in one of our laboratories indicate that the rat SCN may show ER- $\beta$ immunoreactivity, the extent of expression of the corresponding peptide in hamster SCN is unknown.

The transmitter content of oestrogen-responsive neurones afferent to the SCN is unknown. Substance P (61) and GABA (62) have been identified in ER- $\alpha$-containing neurones. Considering reports that GABA agonists and blockers affect light-induced phase shifts of circadian rhythms (63), and evidence for substance $\mathrm{P}$ innervation of the SCN (28) and substance $P$ modulation of circadian rhythms (64), these two transmitters are particularly good candidates as mediators of E2 effects on the circadian system.

The circadian system of rodents also participates in the generation of the oestrogen-induced prooestrous surge of luteinizing hormone $(\mathrm{LH})$, which induces ovulation (for a recent review see (65)). It is not known at which level the interaction between the ovarian and the circadian signals occur. The presence of ER $\alpha$-ir cells afferent to the SCN opens the possibility that these cells may provide the SCN with information about ovarian status critical to the circadian 
gating of the LH surge. We have previously shown that SCN cells project to $\mathrm{ER} \alpha$-ir cells in different areas of the lateral septum, preoptic area, bed nucleus of the stria terminalis, and hypothalamus (23). Thus, the circadian system might be placed either 'downstream' or 'upstream' of the cells which monitor oestrogen levels, and the possibility exists that the LH surge is the result of mutual interaction between SCN cells and their ER- $\alpha$-containing afferents and efferents.

In summary, this study provides evidence for widespread innervation of the SCN by cells that contain oestrogen receptors. High percentages of $\mathrm{SCN}$ afferents are $\mathrm{ER} \alpha$-ir in some regions of the preoptic area and the amygdala. Given the absence of classical ovarian steroid binding sites in the $\mathrm{SCN}$, the neuroanatomical pathways described in this study may serve as a substrate for the ovarian steroid control of circadian behaviour, as well as for the interaction between the circadian and reproductive systems that leads to the generation of the LH surge.

\section{Acknowledgements}

This study was supported by NSF grant IBN93-19653 and NIH grant RO1-44132. J.D.B. and E.L.B. were supported by NIMH Research Scientist Development Awards MH01312 and MH00914, respectively. H.I. was partially supported by a gaduate student fellowship of the Ministry of Education of Argentina. We thank Richard Hurlbut for his care of animals.

\section{Accepted 11 December 1998}

\section{References}

1 Wang GH. The relation between 'spontaneous' activity and oestrous cycle in the white rat. Comp Psychol Monogr 1923; 2: 1-27.

2 Richards MPM. Activity measured by running wheels and observation during the oestrous cycle, pregnancy and pseudopregnancy in the golden hamster Anim Behav 1966; 14: 450-458.

3 Gerall AA, Napoli AM, Cooper UC. Daily and hourly estrous running in intact, spayed, and estrone implanted Rats Physiol Behav 1973; 10: $225-229$.

4 Morin LP, Fitzgerald KM, Zucker I. Estradiol shortens the period of hamster circadian rhtyhms. Science 1977; 196: 305-307.

5 Albers HE, Gerall AA, Axelson JF. Effect of reproductive state on circadian periodicity in the rat. Physiol Behav 1981; 26: 21-25.

6 Wollnik F, Turek FW. Estrous correlated modulations of circadian and ultradian wheel-running activity rhythms in LEW/Ztm rats. Physiol Behav 1988; 43: 389-396.

7 Widmaier EP, Campbell CS. Interaction of estradiol and photoperiod on activity patterns in the female hamster. Physiol Behav 1980; 24: 923-930.

8 Takahashi JS, Menaker M. Interaction of estradiol and progesterone: effects on circadian locomotor rhythm of female golden hamsters. Am J Physiol 1980; 239: R497-R504.

9 Albers HE. Gonadal hormones organize and modulate the circadian system of the rat. Am J Physiol 1981; 10: R62-R66.

10 Rodier WI III. Progesterone-estrogen interactions in the control of activity-wheel running in the female rat. J Comp Physiol Psychol 1991;74: 365-373.

11 Rodier WI III, Segal S. The effect of progesterone on the activity-wheel running of ovariectomized rats. Horm Behav 1977; 9: 214-221.

12 Axelson JF, Gerall AA, Albers HE. Effect of progesterone on the estrous activity cycle of the rat. Physiol Behav 1981; 26: 631-635.

13 Morin LP. Effect of ovarian hormones on synchrony of hamster circadian rhythms. Physiol Behav 1980; 24: 741-749.

14 Morin LP, Cummings LA. Splitting of wheelrunning rhythms by castrated or steroid treated male and female hamsters. Physiol Behav 1982; 29: $665-675$.

15 Thomas EMV, Armstrong SM. Effect of ovariectomy and estradiol on unity of female rat circadian rhythms. Am J Physiol 1989; 26: R1241-R1250.

16 Ralph MR, Foster RG, Davis FC, Menaker M. Transplanted suprachiasmatic nucleus determines circadian period. Science 1990; 247: 975-978.

17 Clark JH, Mani SK. Actions of ovarian steroid hormones. In: Knobil E, Neill JD, eds. The Physiology of Reproduction. New York: Raven Press Ltd, 1994: 1011-1059.

18 Pfaff DW, Schwartz-Giblin S, McCarthy MM, Kow L-M. Cellular and molecular mechanisms of female reproductive behaviors. In: Knobil E, Neill JD, eds. The Physiology of Reproduction. New York: Raven Press Ltd, 1994: 107-220.

19 McEwen BS. Non-genomic and genomic effects of steroids on neural activity. Trends Pharmacol Sci 1991; 12: 141-147.

20 Ramirez VD, Zheng JB, Siddique KM. Membrane receptors for estrogen, progesterone, and testosterone in the rat brain: fantasy or reality. Cell Mol Neurobiol 1996; 16: 175-198.

21 Cintra A, Fuxe KH, Härfstrand A, Agnati LF, Miller LS, Greene JL, Gustaffson J-Å. On the cellular localization and distribution of estrogen receptors in the rat tel- and diencephalon using monoclonal antibodies to human estrogen receptor. Neurochem Int 1986; 8: 587-595.

$22 \mathrm{Li} \mathrm{H-Y,} \mathrm{Blaustein} \mathrm{JD,} \mathrm{de} \mathrm{Vries} \mathrm{GJ,} \mathrm{Wade} \mathrm{GN.} \mathrm{Estrogen-receptor}$ immunoreactivity in hamster brain: preoptic area, hypothalamus and amygdala. Brain Res 1993; 631: 304-312.

23 de la Iglesia HO, Blaustein JD, Bittman EL. The suprachiasmatic area of the female hamster projects to neurons containing estrogen receptors and GnRH. Neuroreport 1995; 6: 1715-1722.

24 Pfaff DW, Keiner M. Atlas of estradiol-concentrating cells in the central nervous system of the female rat. J Comp Neurol 1973; 151: 121-157.

25 Krieger MS, Morrell JI, Pfaff DW. Autoradiographic localization of estradiol-concentrating cells in the female hamster brain. Neuroendocrinology 1976; 22: 193-205.

26 Simerly RB, Chang C, Muramatsu M, Swanson LW. Distribution of androgen and estrogen receptor mRNA-containing cells in the rat brain: an in situ hybridization study. J Comp Neurol 1990; 294: 76-95.

27 Pickard GE. The afferent connections of the suprachiasmatic nucleus of the golden hamster with enphasis on the retinohypothalamic projection. J Comp Neurol 1982; 211: 65-83.

28 Morin LP, Blanchard J, Moore RY. Intergeniculate leaflet and suprachiasmatic nucleus organization and connections in the golden hamster. Visual Neurosci 1992; 8: 219-230.

29 Meyer-Bernstein EL, Morin LP. Differential serotonergic innervation of the suprachiasmatic nucleus and the intergeniculate leaflet and its role in circadian rhythm modulation. J Neurosci 1996; 16: 2097-2111.

30 Moga MM, Moore RY. The organization of neural inputs to the suprachiasmatic nucleus in the rat. J Comp Neurol 1997; 389: 508-534.

31 Watson RE Jr, Wiegand SJ, Clough RW, Hoffman GE. Use of cryoprotectant to mantain long-term peptide immunoreactivity and tissue morphology. Peptides 1986; 7: 155-159.

32 Paxinos G, Watson C. The Rat Brain in Stereotaxic Coordinates, 2nd edn. Orlando: Academic Press, 1986.

33 Price JL, Russchen FT, Amaral DG. The limbic region. II. The amygdaloid complex. In: Bjšrklund A, Hšrkfelt T, Swanson LW, eds. Handbook of Chemical Neuroanatomy. Amsterdam: Elsevier Science Publishers B.V., 1987: 279-485.

34 Coolen LM, Wood RI. Reciprocal connections between neurons in the medial amygdala of the male syrian hamster that process chemosensory or hormonal signals. Soc Neurosci Abstr 1996; 22: 557.7.

35 Lehman MN, Jansen HT, Goodman RL, Wood RI, Coolen LM. Simultaneous demonstration of anterograde and retrograde connections in the brain: co-injections of BDA and cholera toxin. Soc Neurosci Abstr 1997; 23: 532.3 .

36 Alheid GF, de Olmos JS, Beltramino CA. Amygdala and extended amygdala. In: Paxinos G, ed. The Rat Nervous System, San Diego: Academic Press, Inc. 1995: 495-578.

37 Blaustein JD, Turcotte JC. Estradiol-induced progestin receptor immunoreactivity is found only in estrogen receptor-immunoreactive cells in Guinea pig brain. Neuroendocrinology 1989; 49: 454-461.

38 Luppi P-H, Fort P, Jouvet M. Iontophoretic application of unconjugated cholera toxin B subunit $(\mathrm{CTb})$ combined with immunohistochemistry of neurochemical substances: a method for transmiter identification of retrogradely labeled neurons. Brain Res 1990; 534: 209-224.

39 Gomez DM, Newman SW. Differential projections of the anterior and 
posterior regions of the medial amygdaloid nucleus in the syrian hamster. J Comp Neurol 1992; 317: 195-218.

40 Canteras NS, Simerly RB, Swanson LW. Organization of projections from the medial nucleus of the amygdala: a PHAL study in the rat. J Comp Neurol 1995; 360: 213-245.

41 Mizukami S, Nishizuka M, Arai Y. Sexual differences in nuclear volume and its ontogeny in the rat amygdala. Exp Neurol 1983; 79: 569-575.

42 Dyer RG, MacLeod NK, Ellendorff F. Electrophysiological evidence for sexual dimorphism and synaptic convergence in the preoptic and anterior hypothalamic areas of the rat. Proc R Soc Lond [Biol] 1976; 193: 421-440.

43 Simerly RB, Swanson LW. Projections of the medial preoptic nucleus: a Phaseolus vulgaris leucoagglutinin anterograde tract-tracing study in the rat. J Comp Neurol 1988; 270: 209-242.

$44 \mathrm{Gu}$ GB, Simerly RB. Projections of the sexually dimorphic anteroventral periventricular nucleus in the female rat. J Comp Neurol 1997; 384: $142-164$.

45 Watts AG, Swanson LW, Sanchez-Watts G. Efferent projections of the suprachiasmatic nucleus. I. Studies using anterograde transport of phaseolus vulgaris leucoagglutinin in the rat. J Comp Neurol 1987; 258: $204-229$.

46 Kalsbeek A, Teclemariam-Mesbah RP, Pévet P. Efferent projections of the suprachiasmatic nucleus in the golden hamster (Mesocricetus auratus). J Comp Neurol 1993; 332: 293-314.

47 Morin LP, Goodless-Sanchez N, Smale L, Moore RY. Projections of the suprachiasmatic nuclei, subparaventricular zone and retrochiasmatic area in the golden hamster. Neuroscience 1994; 61: 391-410.

48 van der Beek EM, Wiegant VM, van Oudheusden HJC, van der Donk HA, van den Hurk R, Buijs RM. Synaptic contacts between gonadotropin-releasing hormone-containing fibers and neurons in the suprachiasmatic nucleus and perichiasmatic area: an anatomical substrate for feedback regulation? Brain Res 1997; 755: 101-111.

49 Rauth-Widmann B, Fuchs E, Erkert HG. Infradian alteration of circadian rhythms in owl monkeys (Aotus lemurinus griseimembra): an effect of estrous? Physiol Behav 1996; 59: 11-18.

50 Ruiz de Elvira MC, Persaud R, Coen CW. Use of running wheels regulates the effects on the ovaries on circadian rhythms. Physiol Behav 1992; 52: 277-284.

51 Wade GN, Zucker I. Modulation of food intake and locomotor activity in female rats by diencephalic hormone implants. J Comp Physiol Psychol 1970; 72: $328-336$
52 Fahrbach SE, Meisel RL, Pfaff DW. Preoptic implants of estradiol increase wheel running but not the open field activity in female rats. Physiol Behav 1985; 35: 985-992.

53 Kennedy GC. Hypothalamic control of the endocrine and behavioral changes associated with oestrus in the rat. J Physiol 1964; 172: 383-392.

54 King JM. Effects of lesions of the amygdala, preoptic area, and hypothalamus on estradiol-induced activity in the female rat. J Comp Physiol Psychol 1979; 93: 360-367.

55 Wade GN, Schneider JE. Metabolic fuels and reproduction in female mammals. Neurosci Biobehav Rev 1992; 16: 235-272.

56 Shimura M, Harata N, Tamai M, Akaike N. Allosteric modulation of $\mathrm{GABA}_{\mathrm{A}}$ receptors in acutely dissociated neurons of the suprachiasmatic nucleus. Am J Physiol 1996; 270: C17264-C31734.

57 Kuiper GGJM, Enmark E, Pelto-Huikko M, Nilsson S, Gustafsson JÅ. Cloning of a novel estrogen receptor expressed in rat prostate and ovary. Proc Natl Acad Sci USA 1996; 93: 5925-5930.

58 Shughrue PJ, Komm B, Merchenthaler I. The distribution of estrogen receptor- $\beta$ mRNA in the rat hypothalamus. Steroids 1996; 61: 678-681.

59 Shughrue PJ, Lane MV, Merchenthaler I. Comparative distribution of estrogen receptor $\alpha$ - and $\beta$-mRNA in the rat central nervous system. J Comp Neurol 1997; 388: 507-525.

60 Shughrue PJ, Scrimo P, Lane M, Askew R, Merchenthaler I. The distribution of estrogen receptor- $\beta$ mRNA in forebrain regions of the estrogen receptor-(knockout mouse. Endocrinology 1997; 138: 5649-5652.

61 Akesson TR, Micevych PE. Estrogen concentration by substance P-immunoreactive neurons in the medial basal hypothalamus of the female rat. $J$ Neurosci Res 1988; 19: 412-419.

62 Flügge G, Oertel WH, Wuttke W. Evidence for estrogen-receptive GABAergic neurons in the preoptic/anterior hypothalamic area of the rat brain. Neuroendocrinology 1986; 43: 1-5.

63 Gillespie CF, Mintz EM, Marvel CL, Huhman KL, Albers HE. GABA A and $\mathrm{GABA}_{\mathrm{B}}$ agonists and antagonists alter the phase-shifting effects of light when microinjected into the suprachiasmatic region. Brain Res 1997; 759: $181-189$.

64 Piggins HD, Rusak B. Effects of microinjections of substance P into the suprachiasmatic nucleus region on hamster wheel-running rhythms. Brain Res Bull 1997; 42: 451-455.

65 van der Beek EM. Circadian control of reproduction in the female rat. In: Buijs RM, Kalsbeek A, Romijn HJ, Pennartz CMA, Mirmiram M, eds. Progress on Brain Research. Amsterdam: Elsevier, 1996: 293-318. 